\title{
Courts, Law, Language and Culture
}

\author{
Ditlev Tamm
}

\begin{abstract}
This article deals with some questions of legal language in the Nordic countries. It stresses the fact that, while there is no common legal language among these countries, there is still a strong common understanding even though each language (i.e., Danish, Norwegian and Swedish; Finnish is a different language) has also developed its own terminology. Nordic legal language has its roots in the first written form of the law in the years before and after 1200. Later, legal language was influenced by the German language, and, to some degree, more recently by English. The language of Nordic courts was always the vernacular. At the university, Latin was used until the eighteenth century (in dissertations still in the first part of the nineteenth century), but today studies of law are carried out in Nordic languages. There remains a great need for scholarly works on Nordic law in Nordic languages at a time when the balance between international orientation and the necessity of producing scholarly works in the national language is an issue to be discussed.
\end{abstract}

\section{Introduction}

There exists neither a common Nordic legal language nor a Nordic common law. ${ }^{1}$ Around 1900, when Germany adopted its new civil code, Nordic voices were speaking in favour of a Nordic civil code common to all Nordic countries, but that remained a vision. ${ }^{2}$ Each country still has its own legal system and its own language. All statutes or court decisions are written in the national language: Danish, Finnish, Icelandic, Norwegian or Swedish.

\footnotetext{
${ }^{1}$ Regarding this, see Letto-Vanamo et al. (2019).

${ }^{2}$ The most important example being a lecture from 1899 by the Danish professor Julius Lassen, in which he discusses the necessity for a new Danish Code and refers to the possibility that such a code could develop into a Nordic civil code.
}

D. Tamm (凶)

University of Copenhagen, Karen Blixens Plads 16, 2300 København S, Denmark

e-mail: ditlev.tamm@jur.ku.dk 
However, Nordic lawyers mostly do—or at least at official Nordic lawyers' meetings are supposed to-understand each other when they speak or write in their own language. ${ }^{3}$ This is true for Danish, Norwegian and Swedish, whereas Finnish and Icelandic are rightly considered languages so different from the Nordic lingua franca that lawyers from these countries must use one of the other Nordic languages (or English) when meeting to discuss legal issues. Indeed, they meet in quite high numbers at the triennial Nordic Lawyers' Meeting or in other associations and gatherings among specific groups of lawyers such as judges and law professors. 'Speak your own language!' once was considered the rule, but this is no longer maintained with rigour. English often is used among law students and as the language of presentations among younger scholars and by lawyers who do not have a background in Scandinavian languages, such as Finnish lawyers. Sometimes Nordic lawyers may joke about specific legal terms which are unfamiliar to lawyers from other Nordic countries, ${ }^{4}$ and often meaning is lost if a speaker does not speak in a very clear way, using terms that are familiar to most Scandinavians.

Despite these issues, however, there is no movement toward harmonising Nordic legal languages. Just as Nordic law itself is not in general a unified system, legal language also has its peculiarities specific to each Nordic country. ${ }^{5}$ However, it should be noted that other Nordic languages are not considered foreign languages. There is a presumption among lawyers that they should understand each other and should be capable of reading a legal text in the language of another Nordic country.

Even if Nordic languages are similar, they do belong to two different groups within Nordic languages, an East and a West Nordic group. Denmark and Sweden belong to the Eastern group, Norway, Iceland and the Faroe Islands to the Western. However it is more complicated. Denmark and Norway from 1380-1814 were in a union, developed a common legal science since the eighteenth century and therefore shared for a long time common legal terms as did also Sweden and Finland. Thus as to legal language Danish and Norwegian lawyers will have more in common as to terms and difficulties of understanding will be more on a Swedish-Danish line. For a Dane or respectively a Swede understanding legal language of the other country will sometimes need specific knowledge of terms which cannot be deciphered without studying the other system. The legal concepts will often be the same but the terms can be so different, that they are not transparent. As mentioned, the duty not to participate in a decision if you due to family or other relations can be considered partial, in Danish or Norwegian is inhabilitet, and in Swedish jäv. Old Danish words as tinglysning is still in use, when Swedish lawyers would talk of registering, registration, when it comes to the protection of rights over real estate, which in Danish is ejendom and in Swedish a fastighet. A Danish layer would normally feel more or less a home in

\footnotetext{
${ }^{3}$ Nordic legal cooperation is based on a common understanding of Danish, Norwegian and Swedish. Finnish is a Finno-Ugrian language and Icelandic is a Nordic language but not commonly understood by other Nordic lawyers.

${ }^{4}$ Example, the concept of disability or partiality is known in Denmark as inhabilitet and in the Swedish legal language as jäv.

${ }^{5}$ Regarding legal language, see Mattila (2013).
} 
Swedish private law, whereas the procedural system and public law and public law terms would look more different and also here both concepts and those terms will be found that are really different. In these fields lawyers have to be more careful as differences in terms may also indicate differences in the way a concept should be understood, e.g. an ombudsmand can have different functions in the respective countries and in penal law even words who look alike like Danish ran and Swedish rån may indicate different crimes and different ways of structuring the penal system.

\section{The Roots of Nordic Law and Legal Language}

The creation of a Nordic legal language went hand in hand with writing down the law in the Nordic countries, which occurred in the Middle Ages in the years after 1100. The age of some parts of the older Icelandic and Norwegian laws written in the vernacular is still a matter of dispute. With regard to Denmark and Sweden, the situation is more transparent. In Denmark, the first more general writing of the specific law of a region happened in the province of Scania (Skåne, since 1658 a part of Southern Sweden) shortly after 1200 and was followed by codes in the other two provinces (Sealand and Jutland) in the following century. ${ }^{6}$ These laws were written down at a time, when no Danish written language was available. The old laws are thus the first texts of some substance written in the Danish language. We may therefore say, that Danish legal language is actually the basis of - and to some degree createdwritten Danish language. In principle, these old codes are written down in a clear and understandable language and only occasionally include words that do not stem from ordinary language. ${ }^{7}$ The written laws include a series of old Danish words is used to denominate specific economic relations in the family household, transfer of property, division of land in the village, how to pay compensation in a case of manslaughter or to denominate certain crimes. Thus, some ideas of a legal language must have existed before the writing down of the law. ${ }^{8}$

However, the way in which the law in Denmark presents itself as rather well systematised and in a fluent language could suggest as the author someone with a background in studies of the learned language of the Middle Ages: Latin. Many articles in these laws are clearly influenced by the learned law of the time. ${ }^{9}$ We may suspect that it was the wish to codify of the learned Archbishop of Scania, Anders

\footnotetext{
${ }^{6}$ The best-known of these codes is the Law of Jutland, dated 1241. See Tamm and Vogt (2016).

${ }^{7}$ This is especially the case for new concepts introduced in the law on division of a family estate. The word 'capital lot' (hovedlod) was thus used for the ideal part of any partner in a family community. ${ }^{8}$ Such words are especially mentioned and kept in their old Danish version by Anders Sunesen in the Latin work on the law of Scania, mentioned below.

${ }^{9}$ The topics of such articles include, e.g., how to perform baptism, peacekeeping, testaments and succession.
} 
Sunesen, ${ }^{10}$ that shortly after 1200 led to the codification of the local law in Danish at a time when the language used for drafting both royal and private documents was still Latin. Thus, the Danish legal language started out-as in the other Nordic countries - in the vernacular. Even if we may suspect that those who created Nordic medieval law knew Latin, they translated legal concepts into a Nordic language. In Norway, Denmark and Sweden, as in Iceland, law was handled by the local courts in the language understood by local people. ${ }^{11}$

There is a long and unbroken Nordic tradition of using the spoken language as a basis for proceedings in court. In old Anglo-Saxon England before 1066, there was a similar tradition of writing down the law in the English language. However, the later introduction of Law French as legal language complicated the English legal language in a way which has no parallel in the Nordic countries.

\section{Germanic and Romanistic Law}

The old dichotomy between what is seen as law of Germanic origin and what is seen as having roots in Roman law has for a long time divided legal historians, especially German historians. There used to be a tradition of speaking of Germanic law as being opposed to Romanistic law. ${ }^{12}$ Germanic law was law as might be found in the old laws of Germanic peoples, such as Goths, Lombards, Franks, Burgundians, Frisians, Anglo-Saxons and other tribes from the North or East which invaded the Western Roman Empire in the fifth century or settled in that area. This so called Germanic group of law ${ }^{13}$ also included medieval Nordic law and, as it was written in the vernacular (other laws were redacted in Latin), was seen as especially pure Germanic law.

It should be understood from what is said here about Nordic law that we cannot draw any clear distinction between Germanic and Roman/Canon law (or ius commune). When Nordic law was written down-this is perhaps especially the case for Danish, and later Swedish law-Canon law and Roman law were studied at universities in southern Europe, and both systems, especially Canon law, influenced the way Nordic law was put into writing. If, however, we identify Romanistic law with an in-depth study and understanding of the law based on Roman law sources, we are far from such an approach to the law in the medieval Nordic countries.

\footnotetext{
${ }^{10}$ Anders Sunesen, Archbishop of Scania 1201-1223 was educated in Paris and probably also Bologna. Using terminology from Roman law, he wrote a Latin version of the local law of Scania. See Tamm (2017).

${ }^{11}$ See the series of essays in Österberg and Bauger Sogner (2000).

${ }^{12}$ Romanistic law is in principle based on and takes its origin from Roman law.

${ }^{13}$ In Germany there is still talk of 'Germanenrechte' even if the value of such a concept and the existence of sufficient common features to make it a group is highly doubted today.
} 


\section{Roman Law and Canon Law}

In the Middle Ages in particular, the Law of the Church - that is, Canon law-had a great impact on Nordic law and Nordic legal language. The basic institutions of Canon law were created in the Middle Ages and became part of Nordic law. Family law, especially the law of marriage, was governed by Canon law on marriage; indeed, terms from Canon law have become part of family law terminology. And as already noted, the idea of writing down local law and the creation of a somewhat coherent system, as we find it in those laws, may go back to redactors educated in Canon law.

The history of the influence of Roman law and Roman law terminology in the Nordic countries is different from most of the rest of Europe complicated. Roman law never was considered in a Nordic country to be part of Nordic law, nor could it be quoted as such. Students from the Nordic countries studied at other European universities, such as Paris for theology and Bologna for the law and later mostly at German universities. They brought back with them knowledge of the learned 'ius commune, ${ }^{14}$ but such learned law was not implemented in the Nordic countries as it was in Germany. This meant that, in Germany, legal thinking and writing, as well as legal terminology based on Latin developed much earlier than in the Nordic countries. Later in history, but only since the eighteenth century, the impact of German learned law became very important for the education of Nordic lawyers and the making of Nordic legal literature. However, this happened at such late date in legal history that Nordic law was resistant to many concepts and ways of thinking in Roman law and thus kept its basis in the old laws. ${ }^{15}$ This basis in old medieval law combined with later cooperation in the field of law is the main reason for considering Nordic law a 'legal family' of its own. ${ }^{16}$

\section{The Language in Nordic Courts}

Court procedures in the Nordic countries were carried out in the local language, and thus the law was essentially accessible to everyone, with no barrier in the form of a complicated legal language or foreign terms. An exception was the then-eastern part of Sweden, which we today know as an independent Finland. As Finland was the eastern part of Sweden, courts in Finland used Swedish rather than Finnish, whereas Finnish language was used by the majority of the population, mostly ignorant of

\footnotetext{
${ }^{14}$ 'Ius commune' is the term used for Roman and Canon law as distinguished from local law, 'ius proprium', which could only be used when documentation of such a rule was produced before the court.

${ }^{15}$ This is the general explanation for the fact that Roman law was not recognised as the law of the land in the Nordic countries. Roman law, however, played an important role in the education of lawyers and has been a subject taught at the Faculty of Law at the University of Copenhagen since 1479.

${ }^{16}$ See, e.g., Zweigert and Kötz (1998).
} 
Swedish and therefore in need of translation. Since 1863, both Swedish and Finnish have been official languages in Finland and been used by the courts. ${ }^{17}$ Thus, a Finnish judge today is expected to understand both languages and to be able to conduct court proceedings in both Finnish and Swedish. ${ }^{18}$ In Denmark and Norway, there is an uninterrupted tradition of orality in the Supreme Court, as well as of keeping all proceedings in the national language.

Nordic legal language was created in close connection with ordinary language and thus should be understood by-or understandable to-ordinary people. ${ }^{19}$ In early modern times in the Nordic countries, the so-called 'ting' or assembly was the place to make legal decisions. Evidently, however, many cases remained without a decision, while references to a particular statute or law are few, and this institution (held weekly in Denmark but often less frequently in other Nordic countries) institution to a high degree served as a place where controversies could be discussed and compromises or solutions found which were not directly based on written law. The courts thus played a minor role in law-making, and it was only after the establishment of a Royal appeal Court in Sweden ${ }^{20}$ in 1614 and a Supreme Court in Denmark in $1661^{21}$ that conditions were present for the courts to influence law-making.

In Denmark and Norway, modern codes were issued in 1683 and 1687, while in Sweden a new code was issued in $1734 .^{22}$ These codes did not contribute much to the development of legal language. In particular, the Danish and Norwegian codes relied heavily on older law, and thus old terms were still used, however in a modernized form. An example from the Danish code is the law of torts. No general concepts of liability were developed such as the Roman 'iniuria' or 'culpa'. The code would still use medieval terms in matters of torts, and it was only in the eighteenth century that the Supreme Court started to discuss 'culpa' when referring to Roman law as a useful term in Danish law as well to describe the fundamental conditions for liability.

\section{Europeanisation of Nordic Legal Language}

It was only in the eighteenth century that Nordic legal language took a turn towards a more professional vocabulary. In Europe at that time, the study of Roman law was fundamentally changed by the introduction of the so-called 'usus modernus pandectarum', which was a new and systematised way of introducing those parts of

\footnotetext{
${ }^{17}$ The Swedish language, however, dominated in legal scholarship and the higher courts until the beginning of the twentieth century. In 1902 Finnish and Swedish were recognised as having equal status in Finland.

${ }^{18}$ See Mortensen et al. (2019), p. 71.

${ }^{19}$ Even the critical British ambassador to Denmark at that time, Robert Molesworth, recognised the value of the Danish Code being accessible to all due to its style and language; see his (1694) Account of Denmark as it was in the Year 1692. London.

${ }^{20}$ See Korpiola (2014).

${ }^{21}$ Christensen et al. (2015).

${ }^{22}$ See about these codes Tamm (1984).
} 
Roman law which were considered living law. An example is the elementary book known as the introduction to Roman law by J.G. Heineccius according to the so-called 'Institution' system of the Roman lawyer Gaius. ${ }^{23}$ In legal studies Roman law was supplemented by great books on so-called Natural Law, which was free from Roman law but still inspired by Roman law in its description of those rules which should govern human society. The main authors, such as Hugo Grotius, Samuel Pufendorf, Christian Thomasius, Christian Wolff and Emer de Vattel, were widely read in the Nordic countries, and corresponding books in Danish could profit from the many new legal concepts found in these books.

Thus, what we might call Nordic legal science was developing based on a foreign model. The Institutes of Gaius, with their division of legal matters into persons, things and actions (personae, res et actiones), supplied the basic structure in manuals of Danish and Swedish law. We may say that it was the influence of Roman law terminology, Natural law structures combined with the law found in national codes that formed the foundations on which to build a new Nordic law. It was not an attempt to create a Nordic approach to the law, however, but was rather a 'Europeanisation' of the way to handle the old law which constituted a first step towards modern law in the Nordic countries. Germany, the German universities and German methods of studying both Roman law and natural law became extremely important for the new, more theoretical way of studying the law of the Nordic countries.

There was not much professional intercourse between the numerally still rather few Nordic lawyers. Influences and inspiration came from Germany and German legal thinkers. To the degree to which we might speak of a Nordic legal science, it was not created by a common effort but as a result of influence from reading the same 'international bestseller' law books and studying at the same universities. Roman law and Roman legal terminology were at this time introduced into Nordic law, but Roman law itself was not implemented as law by the courts. This meant that the Nordic legal systems were still rather simple in their structure and the legal language was accessible, even if some new concepts needed explanation. ${ }^{24}$ The law of the Nordic countries was far from being any kind of 'civil law' based on a Romanistic tradition, but it was moving in that direction much more than could in any way be compared with English common law and its concepts based on the practice of the English courts.

\footnotetext{
${ }^{23}$ The best-known of these 'Institutionenlehrbücher' was probably Johann Gottlieb Heineccius, Elementa iuris civilis secundum ordinem institutionum: commoda auditoribus methodo adornata, published in several editions since 1723 (Heineccius 1723).

${ }^{24}$ The first, to write about the Natural law more extensively was the professor and author Ludvig Holberg, who in 1714/15 published a book in Danish on natural law mainly following the system of Pufendorf; see Koch (2016).
} 


\section{Nordic Cooperation in the Field of Law}

A new epoch in the Nordic countries started after 1872, when any idea of a political union between the Nordic countries was given up. ${ }^{25}$ Nordic cooperation in the field of law was a substitute in a more restricted area for more ambitious plans for a future Nordic union. ${ }^{26}$ The common basis of this cooperation was a common Nordic tradition of a less theoretical and rather pragmatic approach to the law. The best way of achieving a more solid Nordic law based on statutes, especially within the law of commerce, and not just on unwritten principles was seen as passing single acts on different subject matters (e.g., the law of sale and contracts) rather than through a complete code. In the years after 1900, Nordic law-making was intense, and new legal concepts had to be developed in common.

This work was highly successful and gave Nordic lawyers a common platform of concepts and ways of legal reasoning, especially within private law in a broad sense, including family law, the law of obligations, insurance and company law and in other fields. A basic concept in the law of contracts is 'retshandel', which stems directly from German 'Rechtsgeschäft'. The Nordic law of obligations is deeply indebted to the German Pandektenwissenschaft and the concepts found in the German Civil Code. ${ }^{27}$ However, other branches of the law such as property law and public law still differ considerably from each other in the Nordic countries.

\section{Language and Style in Nordic Courts Today}

The languages of Nordic courts are the Nordic languages. The style of Nordic courts in terms of drafting of decisions is different in each country. Since the enactment of a new Code of Procedure from 1919, Danish courts have been heavily dependent on the principle of orality. All proceedings and all documentation are, in principle, to be presented orally in court. Decisions, on the other hand, are often rather short in their argumentation or reasoning. This is also true for the Danish Supreme Court, which, however, adapts its style of writing to expectations of decisions which are clear as to grounds on which the decision is made. In the Norwegian Supreme Court, the judges in principle have their conclusions stated individually, whereas the Swedish and Finnish Supreme Courts issue longer decisions based on written procedure.

\footnotetext{
${ }^{25}$ Since the 1820 s, the so-called Scandinavian movement aimed at creating a Nordic political union. After the Danish war with Prussia and Austria in 1864, this idea was abandoned as unrealistic due to the lack of support from other Nordic countries.

${ }^{26}$ See Letto-Vanamo and Tamm (2016).

${ }^{27}$ The German civil code (BGB) - the result of the work of several commissions - was based on the leading German school of Roman law at that time, which took its name from Justinian's Pandects. The most important lawyer of this school was Bernhard Windscheid, who wrote a manual of the law of the Pandects, which was also influential in the Nordic countries.
} 
In Nordic courts, one will not find attempts at more personal descriptions of the circumstances as one sometimes finds in British or American superior courts. The language of decisions can normally be characterised as precise and professional but without over-use of legal terminology or in any way attempting a style similar to the brevity of the French Cour de cassation or the extensive argumentation of the European Court of Justice. However, no attempt is made to coordinate the style of Nordic courts.

None of the Nordic countries has adopted the system of constitutional courts. Several reasons can be pointed out for this being rooted in Nordic legal culture, with its respect for parliaments and a deep-seated tradition of law-making not by the courts but by the parliament. There is a continuous democratic tradition in the twentieth century, and no need is felt for constitutional courts as guardians of the constitution. ${ }^{28}$ This does not mean that constitutional review is unknown, but Nordic courts have been restrictive in this respect and have not felt any necessity for specific constitutional courts as in countries with a more blurred democratic past.

\section{Recent Developments}

Since the 1980s, human rights and human rights terminology have played an increasing role in Nordic law. Nordic legal language has become richer in recent years, and new terms are being adapted from international law and American law. A new discussion is arising in academia with regard to balancing the need for legal education with a broader international outlook on the one side with the in-depth study of national law on the other side, which is greatly needed by the courts and also by practicing lawyers.

Actually, the legal language as such of the Nordic countries does not seem at the moment endangered. Since the Middle Ages, there has been a tendency to incorporate terms from foreign law and use them alongside older Nordic terms. Sometimes, one might even feel that the Nordic countries are going too far in maintaining their own terms at the cost of international understanding. Legal Latin is only kept in a few expressions. ${ }^{29}$ As certain Latin words and expressions are common to lawyers in both continental Europe and the Anglo-Saxon world, the ignorance of Latin terms makes the understanding of terms of foreign law more difficult for Nordic students than for students from countries in which knowledge of Latin terms is upheld.

A possible danger for the future development national legal language, however, is the extensive use of English for academic purposes. Articles in English published in a recognised foreign law review are usually ranked higher in the academic evaluation systems than books on national law aimed at ordinary Danish or Finnish lawyers,

\footnotetext{
${ }^{28}$ See Husa et al. (2019), pp. 41-60 and Letto-Vanamo (2021).

${ }^{29}$ E.g., culpa for fault, mora for delay, condictio indebiti, litis pendens and other expressions from procedural law.
} 
who normally will not read articles in English language reviews. ${ }^{30}$ This may also lead to a neglect of national law by leading academic lawyers and thus a lower quality of literature on national law and in national languages. However, Nordic legal language does not seem to be under pressure. In Finland, an increasing number of academic works are written in English, while in other Nordic countries the tendency is also towards internationalisation of academic life at the law faculties. Big law firms will also often conduct international relations in English, but there remains a great need for national legal scholarship conducted in the national languages aimed at courts and such legal proceedings, which — as the great majority - are basically conducted in a Nordic language. Seen from this last perspective, even if Nordic legal languages as such do not seem endangered, they may become impoverished if too many Nordic scholars choose to publish only in foreign languages.

\section{References}

Christensen JP, Erichsen J, Tamm D (2015) The supreme court of Denmark. Gyldendal, Copenhagen

Heineccius $\mathbf{J}$ (1723) Elementa iuris civilis secundum ordinem institutionum: commoda auditoribus methodo adornata

Husa J (2019) Constitutional mentality. In: Letto-Vanamo P et al (eds) Nordic law in European context. Springer, New York, pp 41-60

Koch S (2016) Moralske Kierne eller Introduction til Naturens- og Folkerettens Kundskab, 1716, Ludvig Holberg (1684-1754). In: Martyn G (ed) The formation and transmission of western legal culture. Books that made the law in the western world. Springer, New York, pp 249-252

Korpiola M (2014) the svea court of appeal in the early modern period: historical reinterpretations and new perspectives. Institutet för Rättshistorisk Forskning, Stockholm

Letto-Vanamo P (2021) Courts and proceedings: some Nordic characteristics. In: Ervo L et al (eds) Rethinking Nordic courts. Springer, Cham

Letto-Vanamo P, Tamm D (2016) Cooperation in the field of law. In: Strang J (ed) Nordic cooperation: a European region in transition. Routledge, London, pp 93-108

Letto-Vanamo P, Tamm D (2019) Nordic legal mind. In: Letto-Vanamo P et al (eds) Nordic law in European context. Springer, New York, pp 1-19

Mattila H (2013) Comparative legal linguistics: language of law, Latin and modern lingua francas. Routledge, London

Molesworth R (1694) Account of Denmark as it was in the Year 1692. London

Mortensen B, Suksi M (2019) Respecting autonomies and minorities. In: Letto-Vanamo P et al (eds) Nordic law in European context. Springer, Cham, pp 61-77

Österberg E, Bauge Sogner S (2000) People meet the law: control and conflict-handling in the courts in the Nordic countries in the post-reformation and preindustrial period. Scandinavian University Press, Oslo

Tamm D (1984) The Danish code of 1683: an early European code in an international context. Scand Stud Law 28:163-180

Tamm D (2017) The liber legis Scaniae: Latin text with introduction, translation and commentaries. Brill, London

Tamm D and Vogt H (2016) The Danish medieval laws: the laws of Scania, Zealand and Jutland. Routledge Medieval Translations, London

\footnotetext{
${ }^{30}$ For more details, see van Gestel and Lienhard (2019).
} 
van Gestel R, Lienhard A (2019) Evaluation academic legal research in Europe. Edward Elgar, London

Zweigert K, Kötz H (1998) An introduction to comparative law. Clarendon Press, London

Open Access This chapter is licensed under the terms of the Creative Commons Attribution 4.0 International License (http://creativecommons.org/licenses/by/4.0/), which permits use, sharing, adaptation, distribution and reproduction in any medium or format, as long as you give appropriate credit to the original author(s) and the source, provide a link to the Creative Commons license and indicate if changes were made.

The images or other third party material in this chapter are included in the chapter's Creative Commons license, unless indicated otherwise in a credit line to the material. If material is not included in the chapter's Creative Commons license and your intended use is not permitted by statutory regulation or exceeds the permitted use, you will need to obtain permission directly from the copyright holder.

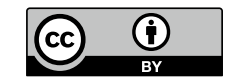

